\title{
PEMBERDAYAAN MASYARAKAT UNTUK MEMBERIKAN PILIHAN PELUANG USAHA MANDIRI BAGI KELOMPOK KOMISI KAUM WANITA GSJA MARANATHA - MALANG
}

\author{
Tri Istining Wardani \\ Jurusan: Administrasi Niaga, Politeknik Negeri Malang \\ tri.istining@polinema.ac.id
}

\begin{abstract}
Abstrak - Tujuan kegiatan PKM ini adalah memberikan pengayaan materi ketrampilan kewirausahaan dalam konsep memberdayakan potensi dan kreativitas pada anggota inti sebuah rumah tangga, khususnya bagi kelompok komisi Kaum Wanita yang ada di GSJA Maranatha Malang. Halayak sasaran adalah kelompok Kaum Wanita dengan pertimbangan mereka sebagai tulang punggung kedua dalam keluarga (setelah suami) mempunyai naluri untuk bertanggung jawab terhadap kesejahteraan keluarga. Melalui kegiatan PKM diharapkan dapat memicu motivasi dan kreatifitas para wanita agar bisa memiliki ketrampilan yang dapat dimanfaatkan secara mandiri untuk membantu perekonomian dan kesejahteraan keluarga.

Kegiatan ini dibagi dalam 2 modul, yang pertama memberikan pembekalan secara teoretis tentang tujuan, manfaat dan tips menjalankan kegiatan kewirausahaan, serta pentingnya menjalankan usaha mandiri bagi seorang wanita untuk meningkatkan kesejahteraan keluarga. Sedangkan yang kedua memberikan pengayaan ketrampilan dasar merajut Teknik Single and Double Crochet dengan teknik Granny Square Pattern, yaitu mengolah benang dengan membentuk sengkelit-sengkelit dengan pertolongan satu batang hakpen sehingga membentuk sebuah benda dengan nilai guna yang baru. Pelatihan dilakukan dengan cara langsung didampingi fasilitator dan menghasilkan sebuah produk yang mempunyai nilai jual, serta masih memiliki pasar yang potensial di masyarakat yaitu produk berupa sarung bantal, sprei, bed-cover dan taplak meja.

Berdasar hasil evaluasi pelatihan, dapat disimpulkan bahwa pelatihan berjalan dengan lancar dan efektif karena khalayak sasaran dapat menyerap ilmu yang disampaikan dan mampu menghasilkan produk jadi sesuai dengan yang ditargetkan dari awal.
\end{abstract}

Kata kunci: Pemberdayaan Masyarakat, Peluang Usaha, Kaum Wanita.

\section{PENDAHULUAN}

\subsection{Latar Belakang}

Hakikatnya bertujuan untuk terwujudnya "perubahan". Yaitu mulai dari titik dimana individu tegerak ingin melakukan suatu sikap dan perilaku kemandirian, termotivasi, dan memiliki keterampilan yang diperlukan untuk melaksanakan pekerjaan dalam norma yang memberikannya rasa keadilan dan kedamaian dalam mencapai tujuan bersama untuk kesejahteraan.
Pola pemberdayaan bagi masyarakat khususnya bagi kelompok ibu-ibu (wanita) merupakan mekanisme yang memberikan peluang untuk memperkaya ilmu pengetahuan dan pengalaman melalui berbagai kegiatan produktif yang dapat mendukung perekonomian keluarga untuk memenuhi kebutuhan sandang dan pangan. Kemunculan paradigma pembinaan terhadap anggota masyarakat khususnya bagi ibu-ibu rumah tangga dipicu oleh arus besar modernisasi yang menghendaki terciptanya peluang kerja secara demokratisasi dalam segala dimensi

Peran serta ibu rumah tangga saat ini layak diperhitungkan dan perlu dikembangkan dalam menyejahterakan keluarga. Bukan berarti semua ibu harus meninggalkan rumah dan anak-anak mereka untuk bekerja mencari nafkah, namun strategi yang baik adalah bagaimana membawa keluarga menuju kesejahteraan baik lahir maupun batin. Menjadi seorang ibu rumah tangga haruslah kreatif memanfaatkan kemampuan, juga realistis dalam berbagi tugas dengan suami dalam membesarkan anakanak. Seorang ibu juga sebaiknya bisa mandiri, tidak melulu tergantung pada suami. Seorang ibu yang mandiri adalah pribadi yang secara proaktif mengambil tindakan-tindakan tertentu untuk mendukung dan membina rumah tangganya. Mandiri bukan berarti melakukan hal sesuka hati sang istri tanpa mempedulikan pendapat suami. Ada banyak cara yang mencerminkan kemandirian, misalnya dalam hal mengelola maupun mendukung pendapatan keluarga. (www.kompasiana.com).

Salah satu cara yang mencerminkan kemandirian dan kreativitas adalah menjalankan kegiatan kewirausahaan atau entrepreneurship. Atau dengan kata lain menjalankan sebuah kegiatan bisnis kecilkecilan. Kegiatan ini semakin meningkat di masyarakat dewasa inikarena kegiatan yang menghasilkan uang ini tidak memerlukan modal besar dan dapat dilakukan dalam skala rumahan. Jadi ibu-ibu pun dapat melakukannya sembari mengurus rumah, mengawasi dan menemani anak-anak mereka, dan akhirnya menghasilkan uang untuk pendapatan keluarga. Melakukan wirausaha, selain menghasilkan uang juga memberi beberapa manfaat lain, yaitu kepuasan batin, karena usaha yang dilakukan tanpa perintah atau suruhan dari seorang atasan, melainkan bebas berkreasi dalam mewujudkan usahanya.

Komisi Kaum Wanita GSJA Maranatha Malang merupakan sebuah kelompok yang mewadahi ibu-ibu rumah tangga dewasa mulai usia 45 tahun keatas. Organisasi Komisi Kaum Wanita berada dibawah naungan GSJA Maranatha yang kepengurusannya 
terletak di Jl AR. Hakim 16 Malang, dan memiliki anggota aktif sekitar 75 orang. Selain kegiatan utamanya di bidang keagamaan, komisi Kaum Wanita juga memiliki kegiatan-kegiatan lain di bidang sosial dalam masyarakat, serta kegiatan pemberdayaan para anggotanya.

\subsection{Rumusan Masalah}

Berdasar analisis situasi diatas, maka rumusan masalah pada kegiatan Pengabdian Masyarakat kali ini adalah: "Bagaimana cara memberikan pengayaan ketrampilan kewirausahaan dalam konsep pemberdayaan bagi kelompok komisi kaum wanita GSJA Maranatha Malang ?

\section{TINJAUAN PUSTAKA}

\subsection{Pemberdayaan Masyarakat}

Pengertian pemberdayaan mempunyai rumusan yang berbeda-beda dalam berbagai konteks dan bidang kajian, hal tersebut dikarenakan belum ada definisi yang tegas mengenai konsep pemberdayaan. Berikut ini beberapa pendapat para ilmuwan yang memiliki komitmen terhadap pemberdayaan masyarakat.

\subsection{Konsep Pemberdayaan}

Pemberdayaan masyarakat adalah proses pembangunan di mana masyarakat berinisiatif untuk memulai proses kegiatan sosial untuk memperbaiki situasi dan kondisi diri sendiri Shardlow (1993) menjelaskan bahwa pengertian mengenai pemberdayaan pada intinya membahas bagaimana individu, kelompok maupun komunitas berusaha mengkontrol kehidupan mereka sendiri dan mengusahakan untuk membentuk masa depan sesuai dengan keinginan mereka. Gagasan ini mengartikan pemberdayaan sebagai upaya mendorong klien untuk menentukan sendiri apa yang harus ia lakukan dalam kaitannya dengan upaya mengatasi permasalahan yang ia hadapi sehingga klien mempunyai kesadaran dan kekuasaan penuh dalam membentuk hari depannya.

Pemberdayaan masyarakat adalah sebuah konsep pembangunan ekonomi yang merangkum nilai-nilai sosial. Konsep ini mencerminkan paradigma baru pembangunan, yakni yang bersifat "people-centered, participatory, empowering, and sustainable" (Chambers, 1995). Konsep ini lebih luas dari hanya semata-mata memenuhi kebutuhan dasar (basic needs) atau menyediakan mekanisme untuk mencegah proses pemiskinan lebih lanjut (safety net), yang pemikirannya belakangan ini banyak dikembangkan sebagai upaya mencari alternatif terhadap konsepkonsep pertumbuhan di masa yang lalu. Konsep ini berkembang dari upaya banyak ahli dan praktisi untuk mencari apa yang antara lain oleh Friedman (1992) disebut alternative development, yang menghendaki "inclusive democracy, appropriate economic growth, gender equality and intergenerational equity”.

Pemberdayaan masyarakat mengacu kepada kata empowerment, yaitu sebagai upaya untuk mengaktualisasikan potensi yang sudah dimiliki sendiri oleh masyarakat. Jadi, pendekatan pemberdayaan masyarakat bertitik berat pada pentingnya masyarakat lokal yang mandiri sebagai suatu sistem yang mengorganisir diri mereka sendiri sehingga diharapkan dapat memberi peranan kepada individu bukan sekedar objek, tetapi justru sebagai subjek pelaku pembangunanyan ikut menentukan masa depan dan kehidupan masyarakat secara umum, (Setiana, 2002).

Dalam kaitannya dengan masyarakat sebagai objek yang akan diberdayakan, pemberdayaan adalah upaya memberikan motivasi/dorongan kepada masyarakat agar mereka memiliki kesadaran dan kemampuan untuk menentukan sendiri apa yang harus mereka lakukan untuk mengatasi permasalahan yang mereka hadapi. Rakyat berada dalam posisi yang tidak berdaya (powerless). Posisi yang demikian memberi ruang yang lebih besar terhadap penyalahgunaan kekuasaan yang berimplikasi terhadap pelanggaran hak-hak rakyat. Dengan demikian, rakyat harus diberdayakan sehingga memiliki kekuatan posisi tawar (empowerment of the powerless). Pemberdayaan (empowerment) dalam studi kepustakaan memiliki kecenderungan dalam dua proses. Pertama, proses pemberdayaan yang menekankan pada proses pemberian atau mengalihkan sebagian kekuasaan, kekuatan atau kemampuan kepada masyarakat agar individu menjadi lebih berdaya, dan kedua, menekankan pada proses menstimulasi, mendorong atau memotivasi individu agar mempuyai kemampuan atau keberdayaan untuk menentukan apa yang menjadi pilihan hidupnya melalui proses dialog.

Mengacu pada beberapa pengertian di atas, pemberdayaan dapat diartikan sebagai upaya membangkitkan kesadaran akan potensi yang dimiliki serta berupaya untuk mengembangkannya sehingga masyarakat dapat mencapai kemandirian. Kemudian dapat disimpulkan bahwa pemberdayaan masyarakat adalah upaya untuk meningkatkan daya atau kekuatan pada masyarakat dengan cara memberi dorongan, peluang, kesempatan, dan perlindungan dengan tidak mengatur dan mengendalikan kegiatan masyarakat yang diberdayakan untuk mengembangkan potensinya sehingga masyarakat tersebut dapat meningkatkan kemampuan dan mengaktualisasikan diri atau berpartisipasi melalui berbagai aktivitas.

\subsection{Tujuan Pemberdayaan}

Payne (Shooving,1997: 266) mengatakan sebagai berikut : "to help clients gain power of decision and action over their own lives by reducing the effect of sosial or personal blocks to exercising cacity and selfconfidence to use power and by transferring power from the environment to clients." Artinya bahwa tujuan pemberdayaan masyarakat adalah untuk membantu masyarakat memperoleh daya untuk mengambil keputusan dan menentukan tindakan yang akan mereka lakukan yang terkait dengan diri mereka sendiri, termasuk mengurangi efek hambatan pribadi dan sosial dalam melakukan tindakan. Hal ini dapat dilakukan melalui peningkatan kemampuan dan rasa percaya diri pada masyarakat untuk menggunakan daya yang ia 
miliki, antara lain melalui transfer daya dari lingkungannya.

Dari paparan tersebut dapat kita simpulkan bahwa tujuan pemberdayaan adalah memampukan dan memandirikan masyarakat terutama dari kemiskinan, keterbelakangan, kesenjangan, dan ketidakberdayaan.

\subsection{Strategi dan Pendekatan Pemberdayaan}

Dalam upaya memberdayakan masyarakat dapat dilihat dari tiga sisi, yaitu ; pertama, menciptakan suasana atau iklim yang memungkinkan potensi masyarakat berkembang (enabling). Disini titik tolaknya adalah pengenalan bahwa setiap manusia memiliki potensi atau daya yang dapat dikembangkan. Kedua, memperkuat potensi atau daya yang dimiliki masyarakat (empowering), upaya yang amat pokok adalah peningkatan taraf pendidikan, dan derajat kesehatan, serta akses ke dalam sumber-sumber kemajuan ekonomi seperti modal, lapangan kerja, dan pasar. Ketiga, memberdayakan mengandung pula arti melindungi. Dalam proses pemberdayaan, harus dicegah yang lemah menjadi bertambah lemah.

Strategi pemberdayaan masyarakat dalam bantuan PPK ini diwujudkan dalam bentuk: 1) partisipasi masyarakat dalam merencanakan, melaksanakan, dan melestarikan pembangunan; 2) pemberian kepercayaan kepada masyarakat untuk memilih kegiatan yang dibutuhkan; 3) pemihakan pada penduduk miskin; 4) pemberian akses informasi kepada setiap penduduk desa mengenai peluang, kebebasan memilih, dan memutuskan; 5) penciptaan suasana kompetisi yang sehat dalam pengajuan usulan kegiatan; 6) penerapan teknologi tepat guna dan padat karya; dan 7) penggalakkan swadaya masyarakat dalam pelaksanaan dan pelestarian pembangunan (Sumodiningrat, 2013)..

Kartasasmita (1997) menyatakan bahwa upaya pemberdayaan masyarakat dapat dilihat dari tiga sisi, yaitu: (1) menciptakan suasana atau iklim yang memungkinkan potensi masyarakat berkembang (enabling); (2) memperkuat potensi atau daya yang dimiliki masyarakat (empowering); dan (3) memberdayakan mengandung pula arti melindungi kelompok lemah agar tidak tertindas oleh kelompok kuat, dan mencegah terjadinya persaingan yang tidak seimbang serta eksplotasi yang kuat atas yang lemah. (Setiana, 2005). .

\subsection{Prinsip-prinsip Pemberdayaan}

Dalam buku "Keadilan, Pemberdayaan dan Penanggulangan Kemiskinan” (Owin Jamasy, 2004) mengaatakan bahwa para pelaku program pemberdayaan harus profesional dan komit untuk mewujudkan seluruh prinsip pemberdayaan ke dalam setiap kegiatan aksi program. Ada 12 prinsip kekuatan internal pelaku pemberdayaan : (1) Para pelaku utama pemberdaya dan seluruh unsur stakeholders, harus berlaku adil. (2) Seluruh unsur stakeholders harus jujur kepada diri sendiri dan orang lain. (3) Kemampuan melakukan problem solving, menumbuhkan dan memasarkan inovasi, asistensi, fasilitasi, promosi, dan social marketing. (4) Kerjasama \& koordinasi seluruh unsur stakeholders berdasar kemitraan. (5) Partisipasi aktif dari seluruh unsur stakeholders. (6) Lingkup dan cakupan program berlangsung secara terpadu. (7) Mengutamakan penggalian dan pengembangan potensi lokal. (8) Aktif melakukan mobilisasi dan peningkatan swadaya yang bertumpu kepada kekuatan masyarakat sendiri/kelompok sasaran (self-reliant development). Mengembangkan metode pembinaan yang konstruktif dan berkesinambungan. (10) Pelaksanaan kegiatan berlangsung secara bertahap. (11) Seluruh unsur stakeholders harus konsisten terhadap pola kerja pemberdayaan. (12) Komitmen serta peduli kepada misi pemberdayaan dan kepada masyarakat miskin.

\subsection{Pemberdayaan Wanita}

Untuk melakukan pemberdayaan bagi wanita (ibu rumah tangga) umumnya dapat menerapkan dasar prinsip pendampingan masyarakat dengan cara: Belajar dari masyarakat, Pendamping sebagai fasilitator, dan Saling belajar.

\subsection{Pembelajaran Pengayaan}

Pengayaan adalah merupakan suatu kegiatan belajar, dikhususkan bagi khalayak sasaran yang memiliki kemampuan belajar lebih, misalkan belajar lebih cepat, menyimpan informasi lebih mudah, keingintahuan lebih tinggi, bepikir mandiri, superior, dan berpikir abstrak, serta memiliki banyak minat. Secara umum pengayaan dapat diartikan sebagai pengalaman atau kegiatan khalayak sasaran yang melampaui persyaratan minimal yang ditentukan oleh kurikulum dan tidak semua peserta didik dapat melakukannya.

Konsep pembelajaran pengayaan dalam kegiatan Pengabdian Kepada Masyarakat kali ini adalah merupakan peningkatan ketrampilan merajut tingkat pemula/dasar yang sebelumnya pernah diberikan kepada khalayak sasaran dengan tujuan untuk memberikan kesempatan pembelajaran baru bagi khalayak sasaran yang memiliki kelebihan sedemikain rupa sehingga mereka dapat mengoptimalkan perkembangan minat, bakat, dan kecakapannya. Materi yang diberikan oleh fasilitator adalah materi merajut tingkat lanjutan yang bisa lebih mudah dipahami oleh khalayak sasaran yang sebelumnya sudah pernah mengikuti pelatihan dasar.

\section{TUJUAN DAN MANFAAT KEGIATAN}

\subsection{Tujuan Kegiatan}

Pengayaan ketrampilan kewirausahaan dalam konsep memberdayakan potensi dan kreativitas terpendam yang ada di lingkungan masyarakat.

Meningkatkan dan mengembangkan budaya kewirausahaan bagi anggota sebuah rumah tangga inti, khususnya bagi kelompok komisi Kaum Wanita di GSJA Maranatha Malang

Menjalin hubungan yang lebih erat antara Politeknik Negeri Malang dengan masyarakat. 


\subsection{Manfaat Kegiatan}

Bagi lembaga, terjalinnya kerja sama dengan pihak luar dan sebagai salah satu bentuk kepedulian Politeknik Negeri Malang pada program Kementerian Pendidikan dan Kebudayaan dalam upaya memberdayakan potensi \& kreativitas Sumber Daya Manusia di masyarakat.

Bagi komisi Kaum Wanita di GSJA Maranatha Malang, mendapatkan pengayaan ilmu pengetahuan dan teknologi, untuk memicu motivasi dan kreatifitas para wanita agar bisa memiliki ketrampilan yang dapat dimanfaatkan secara mandiri untuk membantu perekonomian dan kesejahteraan keluarga.

\section{METODE DAN MATERI}

\subsection{Khalayak Sasaran}

Sebagai sasaran dalam kegiatan Pengabdian Kepada Masyarakat (PKM) ini adalah kelompok komisi Kaum Wanita di GSJA Maranatha Malang.

\subsection{Metode PKM}

Bentuk kegiatan dilakukan dengan materi sbb :

1 Pembekalan Awal, 2 Praktek dan Latihan, 3 Pembekalan Akhir

\subsection{MATERI PELATIHAN DASAR MERAJUT MENGGUNAKAN TEKNIK Granny Square Pattern}

Granny Square Pattern adalah cara membuat proyek rajutan dengan menghasilkan potonganpotongan persegi, kemudian dijahit untuk menyatukan semuanya. Nama Granny Square berasal dari ide awal ketika seorang "nenek" ketika membuat selimut rajutan. Dengan keterbatasannya, selimut yang dibuat berasal dari potongan-potongan rajutan yang berbentuk persegi dan kemudian dijadikan satu dengan cara dijahit. Hal ini merupakan suatu cara yang dapat dipelajari dengan cepat, karena teknik yang digunakan akan sama untuk setiap bagian potongan selimut. Dengan menggunakan Granny Square Pattern, kita bisa merajut sehelai selimut tanpa harus membawanya ke mana-mana, melainkan bisa dengan cara menyelesaikan setiap masing-masing bagian potongan persegi satu persatu, kemudian menjahit untuk menyatukan semuanya.

\subsection{Mempersiapkan Peralatan Merajut :}

Peralatan yang diperlukan dalam latihan:

\section{Hook/hakken/hakpen.}

Hakpen memiliki ukuran bermacam-macam. Penggunaannya disesuaikan dengan ukuran benang. Karena jika hakpen terlalu kecil, hasil rajutannya akan terlalu rapat dan kaku. Begitu juga sebaliknya, apabila hakpen terlalu besar, maka hasil rajutannya akan terlihat besar dan berlubang. Ukuran hakpen ini biasanya tertulis pada pola yang ingin kita gunakan atau pada keterangan berat benang rajut yang telah kita beli.

Ukuran hakpen yang umum digunakan adalah $3 / 0$ atau 4/0, namun untuk proyek membuat Granny
Square Pattern kali ini hakpen yang digunakan adalah no $7 / 0$ menyesuaikan dengan jenis benang yang dipakai.

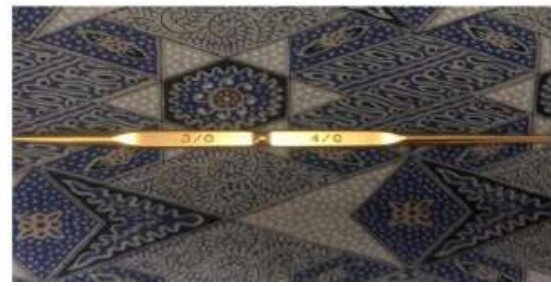

Gambar 1 : Hook / HakPen / Hakken

\subsection{Benang Rajut}

Untuk pelatihan belajar merajut tahap awal/dasar, kita bisa menggunakan benang katun yang umum dan banyak dijual di toko benang rajut dengan banyak pilihan warna. Untuk belajar, disarankan memilih warna-warna terang seperti kuning, putih, biru muda, dan sebagainya. Karena lebih mudah dalam membedakan lubang tusukan (stitch) pada rajutan.

Untuk proyek membuat Granny Square Pattern kali ini, benang yang digunakan adalah jenis Anabelle 5 ply Milk Cotton (100gr). Benang Milk Cotton dipilih dengan pertimbangan karena bahannya yang sangat lembut sehingga sesuai dengan produk akhir yang diinginkan, yaitu selimut, sarung bantal, bed cover dan taplak meja. Dimana setiap khalayak sasaran disediakan masing-masing 3 gulung dengan warna yang berbeda (warna-warni) supaya hasil potonganpotongan Granny Square Pattern nya bisa berwarnawarni dan nampak indah ketika digabung menjadi satu pada tampilan akhir (selimut, sarung bantal, bed cover dan taplak meja) yang dihasilkan.

Contoh variasi seri warna benang rajut yang dibagikan pada khalayak sasaran antara lain dapat dilihat pada gambar 2 dibawah ini.

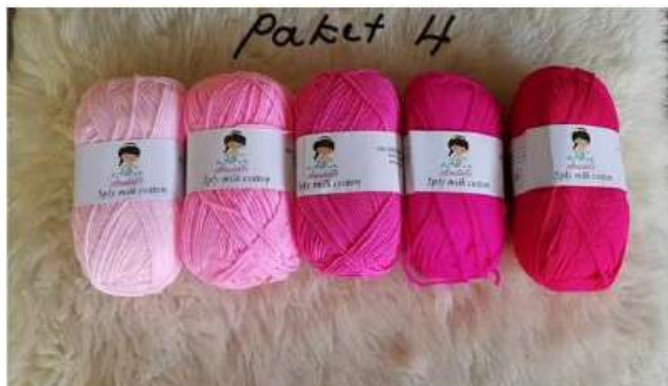
Merah

Gambar 2 : Benang Rajut Anabelle Ply 5 Seri

Beberapa ide pemilihan warna benang adalah sebagai berikut :

Dapatkan tampilan "gypsy" dengan menggabungkan merah, ungu tua, merah muda, kuning, biru muda dan hijau musim semi.

Dapatkan tampilan "country kuno" dengan membuat persegi-persegi berwarna cerah tetapi menyatukan semuanya dengan batasan berwarna hitam.

Dapatkan tampilan Amerika klasik dengan menggabungkan putih, merah, biru, dan kuning pucat.

Jika Anda tidak terlalu mementingkan tampilannya tetapi masih ingin menggunakan cara ini 
untuk merajut sebuah selimut dengan cepat, gunakan hanya dua warna (putih dan biru, contohnya) untuk menghasilkan tampilan yang lebih sederhana.

\section{Gunting}

Gunting digunakan untuk memotong benang rajut yang digunakan dan merapikan hasil rajutan setelah proyek selesai.

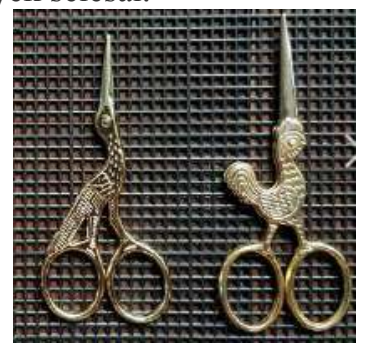

Gambar 5 : Aneka Gunting untuk Benang Rajut

\section{Meteran Kain}

Meteran kain digunakan untuk mengukur masingmasing potongan rajutan Granny Square yang dihasilkan, karena masing-masing ukurannya harus sama supaya tidak menimbulkan masalah ketika nantinya akan disambung menjadi satu. Selain itu digunakan juga untuk mengukur produk akhir yang akan dihasilkan.

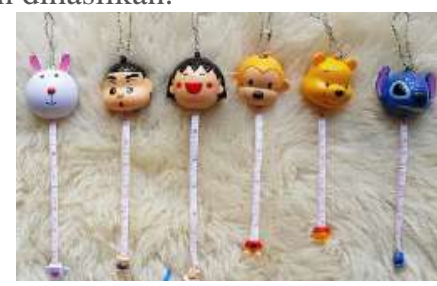

Gambar 6 : Aneka Meteran untuk Mengukur Produk Akhir Rajutan

\section{Marker)}

Alat penanda rajutan / peniti rajut (Stitch

Alat penanda rajutan biasanya kita kaitkan pada benang di ujung rajutan ketika kita berhenti merajut sejenak pada saat proyek yang kita kerjakan masih setengah jadi. Hal ini berfungsi untuk mengamankan pekerjaan kita, karena apabila ujung benang secara tidak sengaja tertarik tidak akan menghancurkan pekerjaan kita.

Alat penanda rajutan juga bisa digunakan ketika kita menyambung benang yang habis atau mengganti warna benang rajutan dengan warna lain sehingga rajutan kita sebelumnya tetap aman.

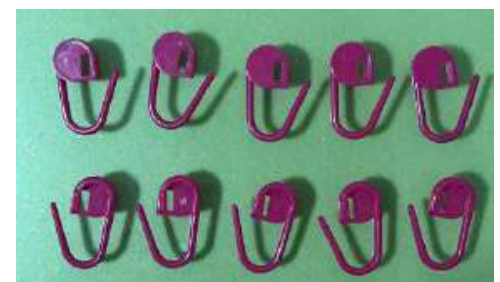

Marker)

Gambar 7 : Aneka Penanda Rajutan (Stitch

\section{Jarum Rajut}

Jarum rajut memiliki lubang jarum yang lebih besar dibandingkan dengan jarum jahit biasa, dan biasanya terbuat dari bahan plastik sehingga ketika kita gunakan tidak akan merusak benang rajut. Jarum sulam berfungsi sebagai alat untuk menggabungkan masing-masing potongan Granny Square yang telah dihasilkan menjadi bentuk yang kita inginkan.

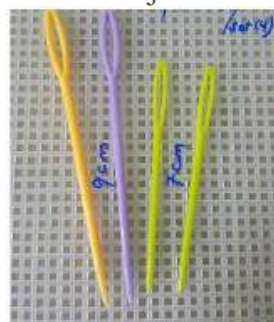

Gambar 8 : Aneka Jarum Rajut

\subsection{GRANNY SQUARE PATTERN}

Rancangan Granny Square Pattern yang akan dibuat oleh khalayak sasaran adalah pattern dasar yang menggunakan 7 putaran lingkaran. Pola dasar akan menggunakan pola rajutan yang sama mulai dari lingkaran awal sampai dengan lingkaran ke 7 . Demikian juga dengan penggunaan warna benang yang digunakan, pola dasar hanya akan meggunakan warna yang sama untuk menyelesaikan 1 potongan granny square, sehingga khalayak sasaran tidak perlu merubah dan menyambung benang warna lain karena relatif sulit dilakukan oleh peserta yang belum punya pengalaman merajut granny square. Pola dasar yang kali ini akan diajarkan fasilitator dapat dilihat pada gambar 1 dibawah ini.

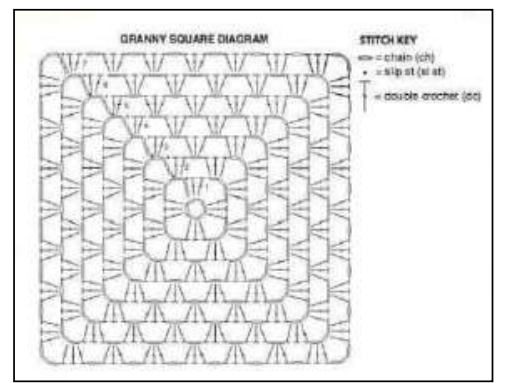

Gambar 9 : Granny Square Diagram

Langkah-langkah pembuatan Granny Square Pattern adalah sebagai berikut :

Membuat Lingkaran Tengah

Gabungkan enam rantai. Buat ikatan di sekitar jarum rajut, lingkarkan benang mengitari jarum kaitannya dan tarik melewati lingkaran pada ikatan tersebut, yang berarti kita telah membuat satu buah ujung rantai. Setelah benang yang kita tarik diputarkan melingkari kait jarum, tarik dan buatlah lingkaran kedua melewatinya, sehingga kita menghasilkan ujung rantai kedua. Tinggalkan setidaknya $10,2 \mathrm{~cm}$ benang pada bagian awal gulungan untuk berjaga-jaga jika kita memerlukannya.

Selipkan jahitan ke ujung rantai pertama. Hal ini akan membentuk sebuah cincin kecil. Tarik sebuah lingkaran baru melewati lingkaran yang sudah ada pada kaitnya, juga melewati ujung rantai.

Gabungkan tiga rantai. Hal ini sama dengan jika Anda melakukan rajutan berganda.

Lakukan rajutan berganda. Buat dua buah rajutan ini pada bagian tengah cincin. 
Rangkaikan dan gandakan lagi. Rangkaikan dua lalu buat tiga buah rajutan berganda di tengah cincin. Lakukan ini sebanyak 3 kali, untuk total 4 grup rb (rajutan berganda).

Selipkan jahitan untuk menyelesaikannya. Selipkan ke bagian atas dari tiga rangkaian yang ada untuk menyelesaikan putaran ini.

Membuat Baris Tengah

Untuk pemula, baris tengah bisa menggunakan warna yang sama dengan lingkaran tengah. Namun bagi kita sudah mulai faham dan terbiasa, bisa kita mulai dengan sebuah warna yang baru. Sebuah warna baru untuk setiap baris yang kita inginkan akan menambah indahnya corak tampilan akhir proyek yg dihasilkan. Mulailah merajut dengan sebuah warna baru dari rg-rt (ruang rantai, ruang yang tersisa dari jahitan rantai di antara kumpulan rajutan berganda).

Rangkaikan tiga lagi. Lakukan hal yang sama dengan saat kita merajut berganda.

Rajut berganda pada bagian sudut-sudutnya. Pada ruang rantai yang telah dijelaskan di atas, lakukan 3 kali rajutan berganda (tetapi jangan lupa bahwa pada set pertama Anda, rajutan berganda yang pertama sebenarnya merupakan rangkaian tiga yang telah Anda lakukan).

Berpindahlah ke ruang rantai berikutnya. Rangkaikan dua melewati kumpulan rajutan ganda dan buatlah rajutan berganda sebanyak tiga buah pada ruang rantai berikutnya. Hal ini akan membuat perseginya mulai terbentuk.

Bentuk bagian sudutnya. Buat 3 rangkaian rantai untuk membentuk sudut persegi lalu lakukan 3 buah rangkaian berganda untuk mengisi ruang rantai tersebut.

Gunakan 1 jahitan rantai jika Anda menginginkan persegi yang lebih bulat dan ketat seperti yang ditunjukkan pada gambar-gambar yang ada.

Lanjutkan sampai barisnya selesai. Lakukan untuk keempat sudut, lalu selipkan jahitan ke atas rangkaian 3 rantai pada sudut pertama untuk menyelesaikan putaran ini. Setiap sudut harus memiliki dua set rajutan berganda (dengan masingmasing set sebanyak tiga buah), yang dipisahkan dengan tiga jahitan berantai.

Dari diagram pada gambar 1, terlihat bahwa kita memerlukan 7 putaran (tidak termasuk lingkaran tengah). Langkah a - f dapat diulang sebanyak 7 kali sampai dengan selesai. Maka 1 potong Granny Square Pattern sudah selesai dibuat.

Kita bisa mengulangi pembuatan potonganpotongan Granny Square Pattern yang lain dengan menggunakan warna yang berbeda sejumlah lebar proyek rajutan yang kita inginkan.

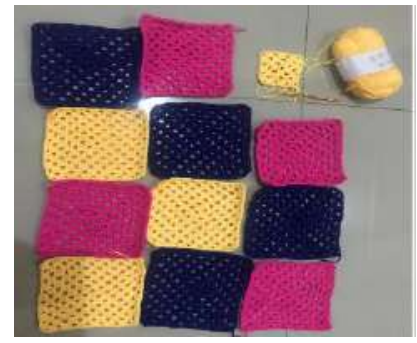

\section{Gambar 10 : Sebagian Potongan Potongan} Granny Square Hasil Karya Khalayak Sasaran

Beberapa khalayak sasaran telah berhasil melakukan modifikasi pattern dasar granny square yang diajarkan oleh fasilitator. Benang yang digunakan untuk membuat 1 potongan granny square tidak lagi hanya menggunakan 1 warna, namun telah mengaplikasikan dengan variasi benang warna lain, yang berarti ada ketrampilan lain yang dipraktekkan, yaitu menyambung benang dengan warna lain.

Selain itu, pattern lingkaran tengah juga telah berhasil dimodifikasi dari bentuk dasar granny square menjadi bentuk matahari. Kedua modifikasi tersebut diatas dapat dilihat pada gambar 8 dibawah ini.

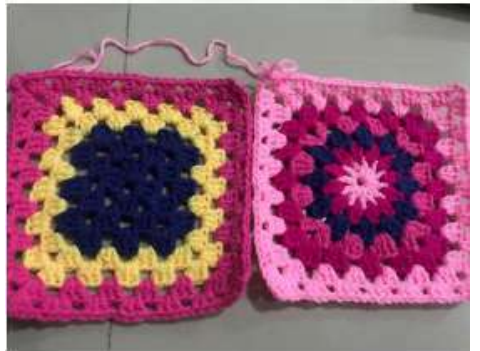

Gambar 11 : Modifikasi Pattern Granny Square Hasil Karya Khalayak Sasaran

\section{Menggabungkan Granny Square}

Potongan-potongan Granny Square yang dihasilkan bisa digabungkan dengan berbagai macam pilihan cara. Sebagian perajut suka menyambungnya dengan cara menjahitnya dengan benang jahit, sebagian lagi menyukai menyambungnya dengan cara merajutnya bersamaan dengan menggunakan sistem rajutan tunggal atau jahitan selip. Salah satu tampilan hasil akhir granny square yang telah digabungkan dapat dilihat pada gambar 9 dibawah ini dalam bentuk bed cover.

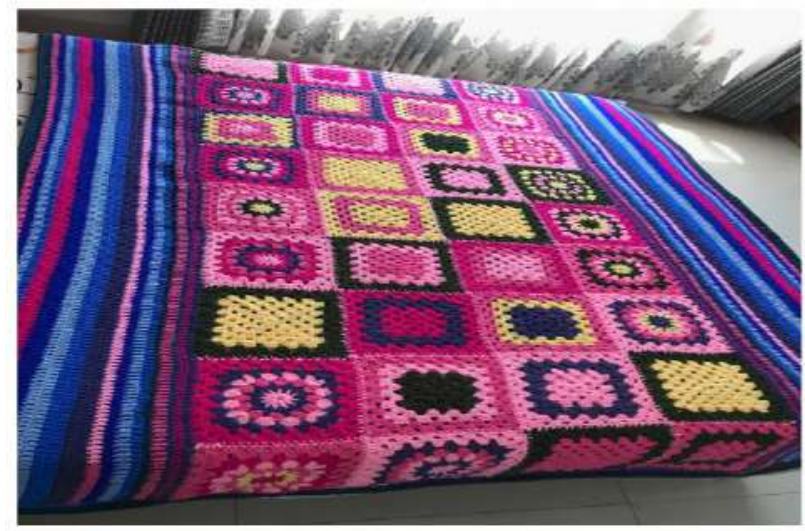

Gambar 12 : Hasil Granny Square Setelah digabungkan dalam bentuk Bed-Cover

Beberapa khalayak sasaran berhasil mengembangkan hasil akhir dari granny square setelah digabungkan menjadi bentuk lain, salah satunya adalah produk Tote Bag / Tas Cangklong seperti terlihat pada gambar 10 dibawah ini. 


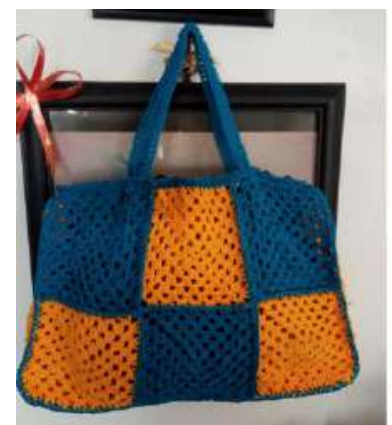

Gambar 13 : Pengembangan Hasil Akhir Gabungan Granny Square dalam bentuk Tote Bag

\section{RANCANGAN EVALUASI}

Rancangan evaluasi dalam kegiatan ini adalah :

\subsection{Evaluasi sebelum kegiatan PKM}

Menganalisis situasi khalayak sasaran, yaitu kelompok komisi kaum wanita GSJA Maranatha Malang melalui wawancara yang dilakukan terhadap para pengurus harian berdasarkan interview guide untuk memudahkan dalam pengumpulan data dan informasi. Isi dari interview guide adalah menggali sejauh mana anggota komisi memiliki potensi \& kreatifitas yang terpendam, dan kegiatan pengayaan pemberdayaan anggota yang sudah dan belum pernah dilaksanakan oleh pengurus.

Berdasarkan evaluasi awal ini diperoleh sebuah kesepakatan bahwa kelompok komisi kaum wanita memerlukan pelatihan dasar membuat barang-barang rajutan dari benang. Untuk tahap awal, target produk jadi yang harus dihasilkan adalah berbentuk dompet rajut dan bross bunga.

\subsection{Evaluasi selama kegiatan PKM}

Evaluasi terhadap penyerapan materi dasar merajut dengan teknik granny square pattern yang diberikan melalui serangkaian pelatihan dan praktek menggunakan benang dan hakpen dengan pengawasan melekat yang oleh 1 orang fasilitator dan sharing antar khalayak sasaran.

Pelatihan dilaksanakan selama 2 hari yaitu pada Hari Jumat, 23 Agustus 2019 dan Senin, 26 Agustus 2019, dimana masing-masing dibagi dalam 2 sesi dengan run-down kegiatan sebagai berikut :

Jam $8.00-10.00$ :

Pendahuluan (Dengan topik : Teori merajut menggunakan granny square pattern, jenis benang dan cara memulai menggunakan benang, jenis hakpen, istilah asing dan kode khusus dalam diagram merajut, cara membaca diagram merajut).

Jam 10.00 - 12.00 :

Praktek membuat Lingkaran awal

Jam $12.00-13.00$ :

Istirahat

Jam $13.00-16.00$ :

Praktek membuat lingkaran ke 2 sampai lingkaran ke 7

*) Pada pertemuan ke 2, praktek ditambah dengan materi menyambung masing-masing potongan granny square.

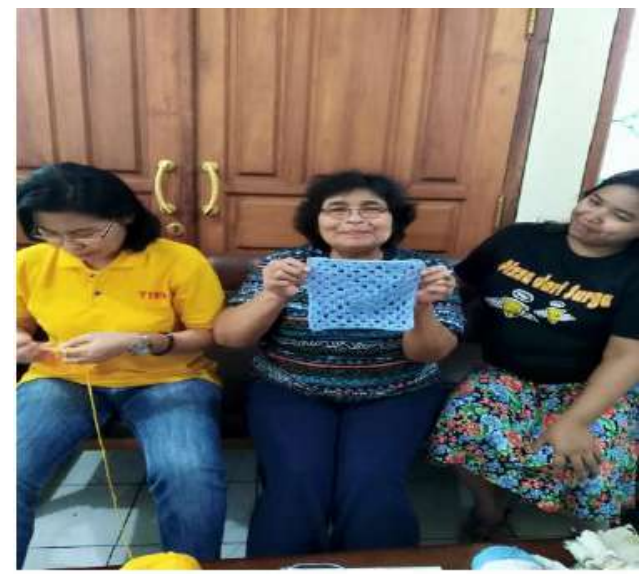
ke -1

Gambar 14 : Pelaksanaan Pelatihan Merajut Hari

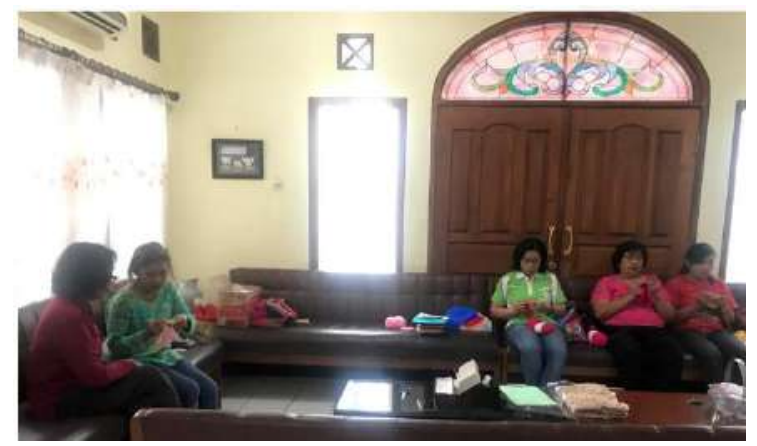

Gambar 15 : Suasana Pelatihan Merajut Hari ke -

2

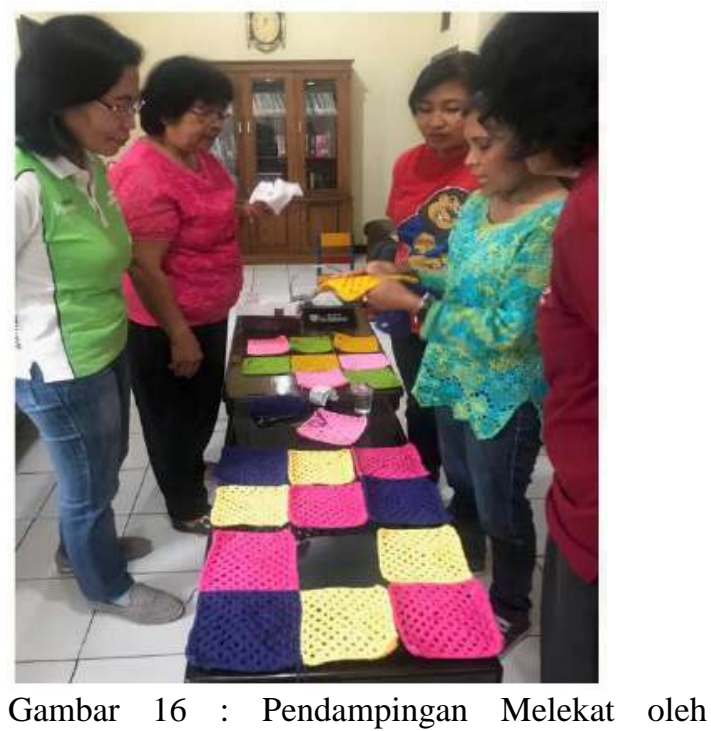

Fasilitator 


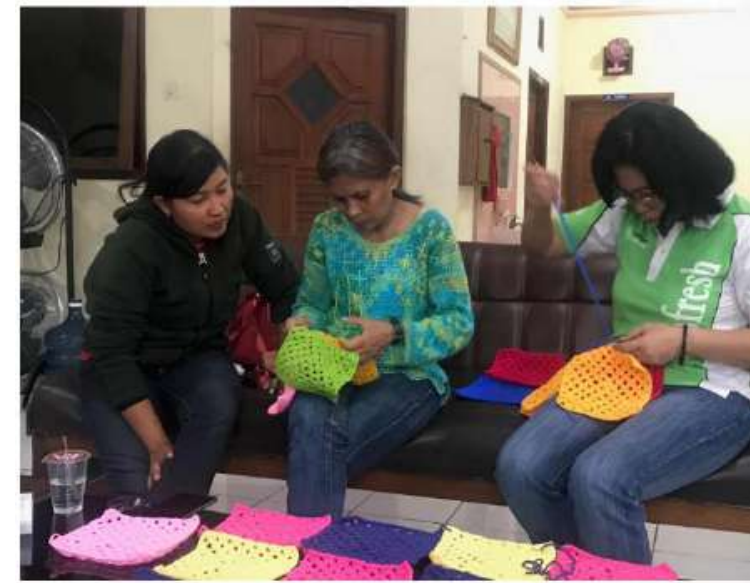

Gambar 17 : Praktek Menggabungkan Granny Square
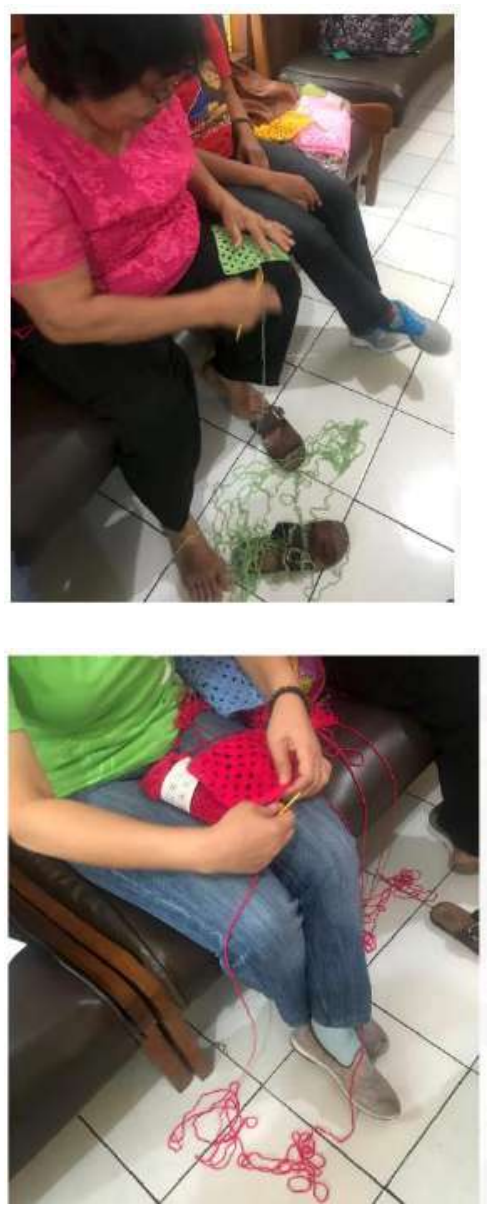

Gambar 18: Proses Belajar Membuat Granny Square ketika Khalayak Sasaran Melakukan Kesalahan (Benang harus diurai kembali)

\subsection{Evaluasi akhir kegiatan PKM}

Untuk mengukur capaian kompetensi mereka masing-masing terhadap tujuan instruksional khusus yang telah ditetapkan di awal, maka pada akhir kegiatan khalayak sasaran akan diberikan pertanyaanpertanyaan dengan metode simulasi, terkait dengan pengertian kewirausaahaan, manfaatnya bagi wanita sebagai individu maupun bagi keluarga, serta tips keberhasilan melakukan usaha mandiri tersebut.

Masing-masing khalayak sasaran juga akan diwajibkan untuk memproduksi sebuah produk yang mempunyai nilai jual (gambar 12 \& 13), yaitu dengan memprosesnya mulai dari bahan mentah sampai dengan produk jadi.

\section{HASIL DAN PEMBAHASAN}

\subsection{Hasil}

Hasil yang dapat dicapai dari kegiatan Pengabdian Kepada Masyarakat dengan judul : PENGAYAAN

KETRAMPILAN KEWIRAUSAHAAN DALAM KONSEP PEMBERDAYAAN BAGI KELOMPOK KOMISI KAUM WANITA GSJA MARANATHA MALANG adalah :

Semakin terbukanya wacana anggota Kaum Wanita terhadap berbagai pilihan peluang usaha mandiri yang memungkinkan untuk dikerjakan.

Semakin meningkatnya ilmu pengetahuan anggota Kaum Wanita terhadap ketrampilan kewirausahaan yang dipilih dengan beberapa pertimbangan relatif mudah dipelajari dan memiliki nilai jual yaitu merajut dengan teknik Granny Square Pattern.

Meningkatknya hubungan antara Politeknik Negeri Malang dengan masyarakat.

\subsection{Pembahasan}

Faktor Penghambat

Pelaksanaan kegiatan Pengabdian Kepada Masyarakat ini terdapat beberapa faktor penghambat sebagai berikut :

- Khalayak sasaran yang sebagian besar adalah ibu rumah tangga yang memiliki kesibukan dalam rumah tangganya. Sebagian khalayak sasaran sudah mendaftar untuk mengikuti pelatihan, namun tidak hadir pada saat pelaksanaan pelatihan karena alasan rumah tangga, sehingga ada beberapa bahan baku pelatihan yang sudah terlanjur diadakan tidak dapat dimanfaatkan dengan maksimal.

- Sebagian khalayak sasaran sudah mengikuti pelatihan pada hari pertama, namun tidak hadir pada pertemuan berikutnya. Point (1) dan (2) tersebut diatas sebenarnya secara ekonomis sudah merugikan pembiayaan pengadaan bahan baku dan penghitungan biaya pelatihan yang harus dibayarkan kepada fasilitator yang daar perhitungannya adalah per kepala.

Masalah tersebut diatas diatasi dengan cara :

(1) Bahan baku yang tersisa, khususnya benang dibagikan kepada khalayak sasaran yang mampu mengembangkan pembuatan produk yang ukurannya memerlukan benang lebih banyak.

(2) Biaya pelatihan yang harus dibayakan kepada fasilitator tidak bisa dikurangi karena ketidakhadiran 
khalayak sasaran, maupun yang hadir hanya 1 pertemuan saja dalam pelatihan. Karenanya direlakan dan dianggap sebagai risk-cost.

Kedua masalah tersebut diatas akan jadi masukan untuk pengadaan kegiatan Pengabdian Kepada Masyarakat yang akan datang untuk lebih berhati-hati dan selektif dalam memilih khalayak sasaran yang memang benar-benar memiliki passion belajar.

\subsection{Faktor Pendorong}

Terdapat beberapa faktor pendorong terselenggaranya kegiatan Pengabdian Kepada Masyarakat sehingga dapat terlaksana dengan lancar adalah sebagai berikut :

Komitmen sebagian besar khalayak sasaran dalam mengikuti kegiatan Pengabdian Kepada Masyarakat sangat besar sekali, dibuktikan dengan animo yang ditunjukkan terhadap materi pelatihan maupun yang diberikan oleh fasilitator dapat diselesaikan dengan baik.

Minat dan semangat belajar yang tinggi, ditunjukkan dengan keberhasilan sebagian besar khalayak sasaran (dengan kapasitas masing-masing) dalam menghasilkan produk akhir, bahkan mampu mengembangkan dan memodifikasi sendiri teori dasar granny square pattern menjadi produk akhir yang jauh diatas standard yang telah ditetapkan.

Fasilitator merupakan pelatih merajut professional yang mumpuni, selama ini berdomisili di Brazilia telah mengembangkan pelatihan dalam banyak kelas-kelas merajut baik secara online maupun offline. Pada saat Pengabdian Kepada Masyarakat dilaksanakan, beliau sedang berkunjung ke tanah air, sehingga bisa membantu memfasilitasi pelatihan dalam kelas tatap muka.

\section{SIMPULAN DAN SARAN}

\subsection{Simpulan}

Dengan telah terselesaikannya kegiatan Pengabdian Kepada Masyarakat untuk kelompok Kaum Wanita GSJA Malang ini, maka semua proses kegiatan mulai dari persiapan awal, pelaksanaan kegiatan sampai dengan evaluasi hasil akhir kegiatan Pengabdian Kepada Masyarakat, dapat diambil beberapa kesimpulan sebagai berikut :

Khalayak sasaran telah mendapatkan pengayaan ilmu pengetahuan dan ketrampilan, khususnya tentang dasar merajut menggunakan teknik granny square pattern sebagai wujud pengayaan ketrampilan kewirausahaan yang memberikan pilihan peluang usaha mandiri.

Hubungan antara Politeknik Negeri Malang dan masyarakat terjalin semakin erat.

\subsection{Saran}

Transfer ilmu pengetahuan dan ketrampilan memerlukan sebuah proses panjang, disarankan agar khalayak sasaran tidak berhenti berlatih hanya pada saat pelaksanaan Pengabdian Kepada Masyarakat saja, tetapi bisa pro-aktif untuk memperdalam pengetahuannya dari berbagai sumber.

\section{DAFTAR PUSTAKA}

[1]. Chambers, Robert. Poverty and Livelihoods: Whose Reality Counts? Uner Kirdar dan Leonard Silk (eds.), People: From Impoverishment to Empowerment. New York: New York University Press, 1995.

[2]. Friedman, John, Empowerment: The Politics of Alternative Development. Cambridge: Blackwell, 1992.

[3]. http://Id.Shvoong.Com/SocialSciences/Economics/2180843-Konsep-DanPengertian PemberdayaanMasyarakat/\#Ixzz2vxbshfm1

[4]. http://Www.MEdukasi.Web.Id/2013/06/Pengertian-PenelitianKualitatif.Html

[5]. http://www.kompasiana.com/sahabatpotret/perem puan-dan-wirausaha-tujuan-manfaat-dan-tipsmenjalankannya_55106c9aa333110037ba823c)

[6]. http://pkbmangingmammiri.blogspot.co.id/2014/0 3/pemberdayaan-ibu-ibu-rumah-tangga.html)

[7]. https://www.funcolorcraft.com/2016/07/panduan -lengkap-belajar-merajut-untuk.html

[8]. Cococraft.blogspot

[9]. https://id.wikihow.com/Merajut-dengan-TeknikCrochet

[10].http://www.zonakreatif.com/panduan-lengkapmerajut-bagi-pemula/

[11].Jamasy, Owin.2004 "Keadilan, Pemberdayaan dan Penanggulangan Kemiskinan”. Bumi Putera:Jakarta.

[12].Latif Abdul. 2007. Pendidikan Berbasis Nilai Kemasyarakatan. Bandung: Refika Aditama.

[13]. Mustofa Kamil. 2009. Pendidikan Nonformal Pengembangan Melalui Pusat Kegiatan Belajar Mengajar (PKBM) di Indonesia (Sebuah Pembelajaran dari Kominkan Jepang). Bandung: Alfabeta.

[14]. Sumodiningrat. 2013. Strategi Pemberdayaan Masyarakat Dalam Pelaksanaan Otonomi Daerah. 